\title{
The Effect of Chronic Alcohol Administration on Bone Mineral Content and Bone Strength in Male Rats
}

\author{
P. D. BROULÍK ${ }^{1}$, J. VONDROVÁ ${ }^{2}$ P. RŮŽIČKA ${ }^{2}$, R. SEDLÁČEK ${ }^{2}$, T. ZÍMA ${ }^{3}$ \\ ${ }^{1}$ Third Medical Clinic, First Medical Faculty, Charles University, Prague, Czech Republic, ${ }^{2}$ Czech \\ Technical University in Prague, Prague, Czech Republic, ${ }^{3}$ Department of Clinical Biochemistry, \\ First Medical Faculty, Charles University, Prague, Czech Republic
}

Received April 3, 2009

Accepted October 6, 2009

On-line November 20, 2009

\section{Summary}

Alcohol use has been identified as a risk factor for the development of osteoporosis. Eight male Wistar rats at two months of age were alcoho-fed (7.6 g $95 \%$ ethanol $/ \mathrm{kg}$ b.w. per day) to evaluate the effects of long-term administration (three months) of alcohol in drinking water. We have used a dose which is considered to be comparable to a dose of 1 liter of wine or 2.5 liters of $12^{\circ}$ beer used in male adults daily. The bones were tested mechanically by a three-point bending test in a Mini Bionix (MTS) testing system. The bones from alcohol-fed rats were characterized by a reduction in bone density as well as in ash, calcium and phosphate content. In alcohol-fed rats the reduction in bone mineral density (10\%) was reflected by about $12 \%$ reduction of mechanical strength of femur $\left(158 \pm 5.5\right.$ vs. $\left.178 \pm 3.2 \mathrm{~N} / \mathrm{mm}^{2}\right)$. Alcohol significantly altered femoral cortical thickness. In our experiment alcohol itself did not exert any antiandrogenic effect and it did not produce changes in the weight of seminal vesicles. Liver function test (GGT, ALP, AST) did not differ between alcohol-fed rats and control rats. Alcohol-induced bone loss is associated with increased bone resorption and decreased bone formation. These results document the efficacy of alcohol at the dose of $7.6 \mathrm{~g} 95 \%$ ethanol $/ \mathrm{kg} \mathrm{b.w.} \mathrm{to} \mathrm{cause} \mathrm{bone}$ loss and loss of bone mechanical strength in intact rats. The results of the present study may be interpreted as supporting the hypothesis of alcohol as a risk factor for osteoporosis.

\section{Key words}

Alcohol • Bone mineral density • Bone strength • Male rats

\section{Corresponding author}

P. Broulík, Third Medical Department, General Teaching Hospital, U Nemocnice 1, 12808 Prague, Czech Republic. E-mail: pbrou@lf1.cuni.cz

\section{Introduction}

Excesive alcohol intake is a well recognized cause of secondary osteoporosis. Alcohol abuse is associated with increased incidence of fractures and complication in fracture healing (Kanis et al. 2005). Higher intake appears to be associated with an increased fracture risk and hip fracture risk (Hoidrup et al. 1999, Mukamal 2007, Iwaniec 2008). There are changes in bone structure detected by histomorphometry and there is a decrease in bone mineral content. Although the relationship between alcohol ingestion and bone disease is evident, the mechanism by which alcohol induces osteoporosis remains unclear. Younger alcoholic patients without other diseases may suffer from an increased risk to develop low bone mineral density (Malik 2009). It is not clear whether alcohol independently affects bone mass. Bone changes may also be produced by factors commonly associated with ethanol abuse like nutritional deficiencies, liver damage and hypogonadism (Odvina et al. 1995, Kim 2003). Thus the etiology of alcoholassociated bone disease is multifactorial. However, not all studies showed an association of alcohol and fracture risk (Berg 2008). The effects of moderate alcohol intake are not thought to be deleterious to skeletal health (Orwoll et al. 2000). Studies in postmenopausal women show a positive association between bone mineral density and alcohol intake, but for men and premenopausal women the bone-alcohol relationship remains unclear (Wosje 2007). The purpose of the current study was to evaluate the effects of chronic administration of moderate ethanol doses on bone mass and strength in intact rats. In our 
experiment we have used three-point bending test which is useful for measuring the mechanical properties of bones from small animals.

\section{Materials and Methods}

Two-month-old male strain rats (Velaz Prague), weighing $205 \mathrm{~g}$ were used for the experiments. They were fed on a standard diet containing $23 \%$ protein, $1.2 \%$ calcium and $0.6 \%$ phosphorus with water ad libitum and were kept in an indirectly illuminated room with controlled temperature at $24 \pm 2{ }^{\circ} \mathrm{C}$. The study was performed in accordance with the Guide for Care and Use of Laboratory Animals published by the National Institutes of Health. The animals were randomly divided into two groups of 8 animals each. Two-month-old male rats drinking daily $7.6 \mathrm{~g}$ of $95 \%$ ethanol/ $\mathrm{kg}$ b.w. daily for 3 months were compared to rats without ethanol. This corresponds to a consumption of 1 liter wine or 2.5 liters of $12^{\circ}$ beer in male adults. Controls were pair-fed isocaloric diet which substitutes calories supplied by ethanol.

In our experiment alcohol was mixed in the drinking water $(190 \mathrm{ml} 95 \%$ ethanol $/ 1000 \mathrm{ml})$. The solution of alcohol in water has been made every day and consumption was measured daily. We have therefore known the exact amount of daily fluid/alcohol consumption. At the end of the experiment the animals were killed, under ether anesthesia, the blood was withdrawn by cardiac puncture and the seminal vesicles were removed, cleaned and weighed.

Femurs were isolated, cleaned of soft tissues. Marrow elements were flushed out with cold saline through a needle inserted into marrow cavity. Finally the bone was weighed and placed in an unstoppered glass vial filled with deionized water which was then put into desiccator. The bones were suspended on a fine wire mesh and weighed in air and in water to accuracy of $0.1 \mathrm{mg}$. Volume and density of the tibia were calculated from the mass in air and in water by Archimedes principle (Kalu et al. 1994). Although assessing bone density using Archimedes principle is time-consuming, it measures true rather than apparent density (Deyhim et al. 2006). The bones were then dried to constant weight and then incinerated for $24 \mathrm{~h}$ at $600{ }^{\circ} \mathrm{C}$ to white ash which was weighed. Bone ashes were then dissolved in hydrochloric acid before determination of calcium and phosphorus content. Bone calcium was measured by the method of (Gitelman 1967) and bone phosphorus according (Kraml 1966).

The activity of plasma tartrate-resistant acid phosphatase (Tr-ACP) (EC 3.1.3.2) was determined as previously described (Štěpán et al. 1983). The activity of plasma bone alkaline phosphatase (ALP), alanine aminotransferase (ALT), asparate aminotransferase (AST), gamma glutamyl transferase (GGT) were determined by automatic Modular Roche analyzer.

Seminal vesicles were cleaned and weighed and the weight was expressed in relative values $(\mathrm{mg} / 100 \mathrm{~g}$ body weight).

For the bone morphology we used the method presented by Beall et al. (1984) and Vanderschueren et al. (1992). Standardized roentgenographs of right femur were made using Philips mamo diagnost 3000 X-ray machine at controlled exposures of $26 \mathrm{kV}$ at $5.5 \mathrm{~mA}$. Morphometric measurements were performed directly on the $\mathrm{X}$ rays after magnification. On the roentgenographs the external, inner bone diameter and cortical width were measured with fine caliper at $40 \%$ of the total length starting from the distal end.

The three-point bending test was used to measure the mechanical properties of the femur. Left femurs were also removed and cleaned of tissue and immediately soft wrapped in gauze soaked in isotonic saline and frozen. After thawing the bones tested were hydrated in distilled water at room temperature $22{ }^{\circ} \mathrm{C}$ over a period of $24 \mathrm{~h}$ before the experiment. Prior to mechanical testing, all soft tissues were removed and specimens were placed on two rounded bars set $20 \mathrm{~mm}$ apart in order to apply the load from medial side of the rat femur (Turner and Burr 1993, Broulík et al. 2005). The MTS Mini Bionix 858.02 biomechanical testing system was used for the three-point bending test. The program, written for the test control in TestWare software, controls cross-head speed and measures important quantities such as load, deflection and time. Bending strength $\sigma_{\text {omax }}$ $\left(\mathrm{MPa}=\mathrm{N} \mathrm{x} \mathrm{mm}^{-2}\right)$ was calculated from the ultimate force $\mathrm{F}_{\max }(\mathrm{N})$ and section modulus of bone $\mathrm{W}_{\text {omin }}\left(\mathrm{mm}^{3}\right)$ where $\sigma_{\text {omax }}=M_{\text {omax }} / \mathrm{W}_{\text {omin }}=F_{\max } \quad . L /\left(\begin{array}{llll}4 & \mathrm{x} & \mathrm{W}_{\text {omin }}\end{array}\right)$ where $\mathrm{M}_{\text {omax }}$ $(\mathrm{N} \times \mathrm{mm})$ is maximal bending moment and $\mathrm{L}(\mathrm{mm})$ is distance between two supporting bars. Ultimate load (force at failure) is the maximum load that a specimen withstands before fracture.

The bones were measured according to the following principle: the bone cross-section at the fracture location was resurfaced by grinding, to get a planar surface perpendicular to the femur axis, and marked by the colored felt-tip pen and scanned by flat tabletop 
scanner at resolution $1200 \times 1200$ dpi that means pixel size $0.021 \times 0.021 \mathrm{~mm}$. The full color digital image obtained from scanner was sent through the process of segmentation. The binary image of the same resolution and size was derived from color image. The binary contains values 0 and 1,1 meaning that the corresponding pixel belongs to the bone cross-section, 0 meaning the pixel does not belong to the bone (Rủžička et al. 2002). The binary image was converted into the program written in MATLAB (Turner 1993). This program calculates every important dimensions of the bone cross-section these are $A, b_{\min }, b_{\max }, J_{\min }$ and $\mathrm{W}_{\text {omin }}$. A refers to the cross-section area, $b_{\min }$ and $b_{\max }$ are minimal and maximal dimensions of the bone cross-section, $\mathrm{J}_{\min }$ is the minimal moment of inertia. $\sigma_{\max }$ expressed as $\left(\mathrm{N} / \mathrm{mm}^{2}\right)$ is bone strength is an intrinsic property of bone.

Load-deflection curves were recorded at the cross-head of $2 \mathrm{~mm} / \mathrm{min}$ by load indicator with a measuring range $0-500 \mathrm{~N}$.

The means $\pm 95 \%$ confidence intervals were computed and the significance of differences between the means was evaluated by an analysis of variance and Duncan's test (1955).

\section{Results}

There were no clinical signs of morbidity in any of the two groups studied. All rats gained body weight during the study but groups given alcohol had smaller weight gains and lower final body weight than the control animals (Table 1). However, the difference did not reach statistical significance. The animals were paired and we did not observe decreased food intake in alcohol-fed animals. Serum calcium, phosphorus, total protein and amylase were not significantly different in either control and alcohol-fed animals. Abnormal liver metabolism was not evident and the ethanol dose had a minimal effect on liver metabolism. Liver function test (gama glutamyl transferase, asparate aminotransferase, alanine aminotransferase) did not differ between alcohol-fed rats and control rats. Serum alkaline phosphatase was significantly lower in the ethanol-fed as compared with the control animals. None of the rats in this study had diagnosis of chronic pancreatitis (normal level of plasma amylase). Plasma tartrate-resistant acid phosphatase (TrACP) (EC 3.1.3.2) levels in ethanol-fed rats were significantly higher than those in controls. The increase in plasma tartrate-resistant acid phosphatase in ethanol-fed rats would be consistent with increase of bone resorption.
No significant changes were observed in the weight of the seminal vesicles a highly androgen dependent tissue in alcohol fed animals (Table 1).

Table 1. Variables of initial and final body weight, density of femur, femur calcium a phosphate content, femoral bone strength, plasma ALP and ACP, AST, ALT, GGT and AMS in individual groups of animals.

\begin{tabular}{|c|c|c|}
\hline & $\begin{array}{l}\text { Controls } \\
\mathbf{n}=\mathbf{8}\end{array}$ & $\begin{array}{l}\text { Alcohol } \\
\mathbf{n}=\mathbf{8}\end{array}$ \\
\hline $\begin{array}{l}\text { Initial body weight } \\
(g)\end{array}$ & $220 \pm 4.2$ & $210 \pm 5.0$ \\
\hline $\begin{array}{l}\text { Final body weight } \\
\text { (g) }\end{array}$ & $302 \pm 5.2$ & $290 \pm 7.0$ \\
\hline $\begin{array}{l}\text { Femur dry weight } \\
\text { (mg) }\end{array}$ & $407 \pm 17$ & $357 \pm 16 *$ \\
\hline $\begin{array}{l}\text { Femur volume } \\
\text { (ul) }\end{array}$ & $379 \pm 9$ & $382 \pm 15$ \\
\hline $\begin{array}{l}\text { Density of femur } \\
(\mathrm{g} / \mathrm{ml})\end{array}$ & $1.620 \pm 0.03$ & $1.480 \pm 0.04 *$ \\
\hline $\begin{array}{l}\text { Femur ash content } \\
(\mathrm{g} / \mathrm{ml})\end{array}$ & $0.734 \pm 0.07$ & $0.645 \pm 0.06 *$ \\
\hline $\begin{array}{l}\text { Femur calcium } \\
(\mathrm{mg} / \mathrm{ml})\end{array}$ & $278 \pm 11$ & $245 \pm 7 *$ \\
\hline $\begin{array}{l}\text { Femur phosphate } \\
(\mathrm{mg} / \mathrm{ml})\end{array}$ & $123 \pm 5$ & $106 \pm 7 *$ \\
\hline $\begin{array}{l}\text { Bone strength } \\
\left(\mathrm{N} / \mathrm{mm}^{2}\right)\end{array}$ & $178 \pm 3.2$ & $158 \pm 5.6^{*}$ \\
\hline $\begin{array}{l}\text { Seminal vesicles } \\
\text { (mg/100 g b.w.) }\end{array}$ & $232 \pm 18$ & $229 \pm 0.4$ \\
\hline $\begin{array}{l}A L P \\
(\mu k a t / l)\end{array}$ & $7.4 \pm 0.16$ & $6.4 \pm 0.58 *$ \\
\hline $\begin{array}{l}\text { Tartrate ACP } \\
(\mu k a t / l)\end{array}$ & $0.44 \pm 0.04$ & $0.60 \pm 0.10 *$ \\
\hline $\begin{array}{l}\text { Calcium } \\
(\mathrm{mmol} / \mathrm{l})\end{array}$ & $2.4 \pm 0.1$ & $2.5 \pm 0.2$ \\
\hline $\begin{array}{l}\text { Phosphate } \\
\text { (mmol/l) }\end{array}$ & $1.2 \pm 0.1$ & $1.3 \pm 0.1$ \\
\hline $\begin{array}{l}A S T \\
(\mu k a t / l)\end{array}$ & $3.1 \pm 1.1$ & $3,6 \pm 1.01$ \\
\hline $\begin{array}{l}A L T \\
(\mu k a t / l)\end{array}$ & $0.53 \pm 0.16$ & $0.71 \pm 0.19$ \\
\hline $\begin{array}{l}\text { Amylasa } \\
(\mu k a t / l)\end{array}$ & $27.9 \pm 4.2$ & $22.9 \pm 4.07$ \\
\hline $\begin{array}{l}G G T \\
(\mu k a t / l)\end{array}$ & $0.04 \pm 0.05$ & $0.06 \pm 0.05$ \\
\hline
\end{tabular}

Data are means \pm S.D., $* \mathrm{p}<0.01$ vs. intact animals. 
The densities of the femurs, ash weights and calcium and phosphorus content of the femur were significantly reduced in alcohol-fed rats, compared with the animals without alcohol $(\mathrm{p}<0.01)$. Three-point biomechanical testing of femurs from alcohol-fed rats revealed significant reduction in cortical strength and energy to failure. In alcohol-fed rats the reduction in bone mineral density $(10 \%)$ was reflected in the reduction of mechanical strength of femur $(158 \pm 5.6$ vs. $178.9 \pm 3.2$ $\mathrm{N} / \mathrm{mm}^{2}$ ), which is reduction about $12 \%$ (Table 1 ).

Femoral length and outer diameter were not significantly different between alcohol-fed rats and control rats. However, alcohol-fed rats had significantly decreased femoral cortical thickness (Table 2).

Table 2. Variables of morphometric measurements on femur in individual groups of animals.

\begin{tabular}{lcc}
\hline & $\begin{array}{c}\text { Controls } \\
\mathbf{n}=\mathbf{8}\end{array}$ & $\begin{array}{c}\text { Alcohol } \\
\mathbf{n = 8}\end{array}$ \\
\hline Femur length $(\mathrm{mm})$ & $39.2 \pm 0.2$ & $39.0 \pm 0.3$ \\
Outer diameter $(\mathrm{mm})$ & $4.18 \pm 0.06$ & $4.15 \pm 0.05$ \\
Inner diameter $(\mathrm{mm})$ & $2.79 \pm 0.08$ & $2.88 \pm 0.05^{*}$ \\
Cortical width $(\mathrm{mm})$ & $1.39 \pm 0.02$ & $1.27 \pm 0.05^{*}$ \\
\hline
\end{tabular}

Data are means \pm S.E.M., $* \mathrm{p}<0.01$ vs. intact animals.

\section{Discussion}

Alcohol causes substantial decreases in femoral density and biomechanical properties of femur in intact rats. We have used a dose which is considered to be comparable to a dose of 1 liter of wine or 2.5 liters of $12^{\circ}$ beer used in male adults daily. The mean values of bone density of the femur were significantly different between the control and alcohol-fed rats. However, bone density and bone mineral content are an indirect measure of bone quality, reflecting the amount and arrangement of the mineral phase but not bone strength itself. In the case of assessing bone density in small animals using Archimedes principle it measures true rather than apparent density (Deyhim et al. 2006).

Measurement of bone mechanical properties is an important tool for evaluating the functional significance of changes in bone mass and/or architecture. Mechanical properties of bone do not depend solely on mineralization, but on the organization and microscopic structure of bone material. Loss of bone strength can arise from changes in spatial distribution of bone material without any loss of osseous tissue or changes in ash composition.

In our experiment there were reductions in the mechanical strength of the midshaft femur in alcohol fed rats when compared to control rats (Table 1). This may be explained by ethanol-induced cortical bone loss (change of cortical width). Histomorphometric studies have shown that in alcohol-fed rats there was a significant reduction in cortical thickness $(p<0.05)$ (Table 2$)$. In alcohol-fed rats the reduction in bone mineral density $(10 \%)$ was reflected in the reduction of mechanical strength of femur $\left(158 \pm 5.5\right.$ vs $\left.178 \pm 3.2 \mathrm{~N} / \mathrm{mm}^{2}\right)$ which is a reduction by about $12 \%$. It is not known whether the effects of alcohol on bone cells are direct. It is possible that alcohol alters the activity, production or binding of growth factors produced by the cells. Complete information concerning the mechanism of the skeletal effects of alcohol is still lacking.

In the present study there was no evidence of liver disease or hypogonadism in any of alcohol-fed rats; therefore the confounding effects of these variables on bone mass were excluded. It appears that prolonged alcohol intake is necessary for the negative effects of alcohol to be observed. Both chronic and acute administration of ethanol can suppress plasma testosterone levels in men and in experimental animals. However, we did not find any significant changes in the weight of the seminal vesicles - a highly androgendependent tissue - after alcohol administration. Our ethanol dose had a minimal effect on liver metabolism. We can assume that ethanol (7.6 g $95 \%$ ethanol $/ \mathrm{kg}$ b.w. per day) was solely responsible for the observed changes in bone metabolism.

High bone turnover states may compromise bone strength by reducing bone mass causing focal areas of weakness in trabeculae and preventing complete mineralization of bone structural units (Ott 2001). The decrease in cortical thickness in alcohol fed rats may result from increased resorption at the endocortical surface or decreased formation at either the endosteal or periosteal surface. Increased TrACP and decreased ALP levels were found in alcohol-fed rats (Table 1).

Our results demonstrate that alcohol causes a loss of bone mass and bone strength, in cortical bone possibly through an increase in bone resorption expressed by increased TrACP. It is known that increased resorption results in a decrease in bone density and is the cause of bone loss in postmenopausal women. Interpretation of the 
data obtained in this study is difficult because the mechanism by which alcohol acts on bone remains unclear. However, several lines of evidence allow some speculation about the significance of alcohol effect on bone.

Alcohol intake is a risk factor for osteoporosis (Cummings et al. 1995, Kanis et al. 2005). There was a significant inhibition of cell proliferation and extracellular matrix synthesis. In vitro studies have shown that alcohol directly increases bone resorption and inhibits bone formation (Santori et al. 2008). In addition animal studies have demonstrated that alcohol ingestion results in bone loss and inhibition of bone matrix synthesis and mineralization in rats (Turner et al. 1987) Increased bone resorption has been demonstrated in alcoholic subjects (Bickle et al. 1993). In rats ethanol consumed during the post-injury period was responsible for the inhibition of bone repair (Chakkalakal et al. 2005).

While we have shown that alcohol affects the bone in rats, its potential effects in humans are still unknown. After long-term treatment of rats with moderate ethanol dose this drug is able to decrease bone mineral density and biomechanical properties of bone suggesting possible efficacy of alcohol to increase fracture risk in humans. The relationship between ethanol use and bone mineral mass is not mediated via an effect on androgen action or abnormal liver metabolism. In our experiments increased bone resorption and reduction in bone formation have been demonstrated in alcohol-fed rats.

\section{Conflict of Interest}

There is no conflict of interest.

\section{Acknowledgements}

This work was supported by the research projects MSM 0021620806 and LC06044 granted by the Ministry of Education Youth and Sports of Czech Republic.

\section{References}

BEALL PT, MISRA LK, YOUNG RL, SPJUT HJ, EVANS HJ, LE BLAME A: Clomiphene protects against osteoporosis in the mature ovariectomized rat. Calcif Tissue Int 36: 123-125, 1984.

BERG KM, KUNINS HV, JACKSON JL, NAHVI S, CHAUDHRY A, HARRIS KA, MALIK R: Association between alcohol consumption and both osteoporotic fracture and bone density. Am J Med 121: 406-418, 2008.

BICKLE D, STESIN A, HALLORAN B, STEINBACH L, RECKER R: Alcohol induced bone disease: relationship to age and parathyroid hormone levels. Alcohol Clin Exp Res 17: 690-695, 1993.

BROULÍK PD, ROSENKRANCOVÁ J, RŮŽIČKA P, SEDLÁČEK R: Effect of alendronate administration on bone mineral density and bone strength in castrated rats. Horm Metab Res 37: 414-418, 2005.

CHAKKALAKAL DA, NOVAK JR, FRITZ ED, MOLLNER TJ, MCVICKER DL, GARVIN KL, MCGUIRE MH, DONOHUE FM: Inhibition of bone repair in rat model for chronic and excessive alcohol consumption. Alcohol 36: 201-214, 2005.

CUMMINGS SR, NEVITT MC, BROWNER WS, STONE K, FOX KM, ENSRUND KE, CAULEY J, BLACK D, VOGT TM: Risk factors for hip fracture in white women. $N$ Engl J Med 3: 767-773, 1995.

DEYHIM F, GARICA K, LOPEZ E, GONZALES J, INO S, GARCIA M, PATIL BS: Citrus juice modulates bone strength in male senescent rat model of osteoporosis. Nutrition 22: 559-563, 2006.

DUNCAN D: Multiple range and multiple F test. Biometrics 11: 1-4, 1955.

GITELMAN H: An improved automated procedure for the determination of calcium in biological specimens. Anal Biochem 18: 521-531, 1967.

HOIDRUP S, GRONBAEK M, GOTTSCHAU A, LAURITZEN JB, SCHROLL M and the Copenhagen Centre for Prospective Population Studies (1999): Alcohol intake, beverage preference and risk of hip fracture in men and women. Am J Epidemiol 149: 933- 1001, 1999.

IWANIEC UT, TREVISIOL CH, MADDALOZZO GF, ROSEN CJ, TURNER RT: Effects of low dose parathyroid hormone on bone mass turnover and ectopic osteoinduction in rat model for chronic alcohol abuse. Bone 42: 695-701, 2008.

KALU DN, HARDIN RR, CECKERHAM R: Evaluation of the pathogenesis of skeletal changes in ovariectomized rats. Endocrinology 115: 507-511, 1994. 
KANIS JA, JOHANSSON H, JOHNELL O, ODEN A, DE LAET C, EISMAN JA, POLS H, TENENHOUSE A: Alcohol intake as a risk factor for fracture. Osteoporosis Int 16: 742, 2005.

KIM MJ, SHIM MS, KIM MK, LEE Y, SHIN YG, CHUNG CH, KWON SO: Effect of chronic alcohol ingestion on bone mineral density in males without liver cirrhosis. Korean J Intern Med 18: 174-180, 2003.

KRAML J: A semiautomated determination of phospholipids. Clin Chim Acta 13: 442-448, 1966.

MALIK R, GASSER RW, KEMMLER G, MONCAYO R, FINKENSTEDT G, KURZ M, FLEISCHHACKER WW: Low bone mineral density and impaired bone metabolism in young alcoholic patients without liver cirrhosis: A cross sectional study. Alcohol Clin Exp Res 33: 375-381, 2008.

MUKAMAL KJ, ROBBINS JA, CAULEY JA, KERN LM, SISCOVICK DS: Alcohol consumption, bone density and hip fracture among older adults: the cariovascular Health study. Osteoporosis Int 18: 593-602, 2007.

ODVINA VC, SAFI I, WOJTOWICZ CH, BARENGOLTS EI, LATHON P, SKAPARS A, DESAI PN, KUKREJA SC: Effect of heavy alcohol intake in the absence of liver disease on bone mass in black and white men. $J$ Clin Endocrinol Metab 80: 2499-2503, 1995.

ORWOLL ES, BEVAN L, PHIPPS KR: Determinants of bone mineral density in older men. Osteoporosis Int 11: 815$821,2000$.

OTT SM: Fractures after long term alendronate therapy. J Clin Endocrinol Metab 86: 1835-1842, 2001.

RŮŽIČKA R, MICHÁLEK J, ROSENKRANCOVÁ J, SEDLÁČEK R: Cross section parameters acquisition from digital images. Proceedings of Workshop Czech Technical University 2002. Prague CTU, B: 910-991, 2002.

SANTORI C, CECCANTI M, DIACINTI D, ATTILIA ML, TOPPO L, D’ERASMO E, ROMAGNOLI E, MASCIA ML, CIPIRANI C, PRASTARO A, CARNEVALE V, MINISOLA S: Skeletal turnover bone mineral density and fractures in male chronic abusers of alcohol. J Endocrinol Invest 31: 321-326, 2008.

ŠTĚPÁN JJ, ŠILINKOVÁ-MÁLKOVÁ E, HAVRÁNEK T, FORMÁNKOVÁ J, ZICHOVÁ J, LACHMANOVÁ J, STRAKOVÁ M, BROULÍK P, PACOVSKÝ V: Relationship of plasma tartrate-resistant acid phosphatase to the bone isoenzyme of serum alkaline phosphatase in hyperpathyroidism. Clin Chim Acta 133: 189-200, 1983.

TURNER CH, BURR DB: Basic biomechanical measurements of bone: a tutorial. Bone 14: 595-608, 1993.

TURNER RT, GREENE VS, BELL NH: Demonstration that ethanol inhibits bone matrix synthesis and mineralization in the rat. J Bone Miner Res 2: 61-66, 1987.

VANDERSCHUEREN DE, VAUTTERCK AMH, SUIKER WJ, WISSER LPC, SCHOT R, BOUILLON R: Bone and mineral metabolism in aged male rats. Short and long term effects of androgen deficiency. Endocrinology 130: 2906-2916, 1992.

WOSJE KS, KALKWARF HJ: Bone density in relation to alcohol intake among men and women in the United States. Osteoporosis Int 18: 391-400, 2007. 